\title{
Multitemporal analysis of the spectral response of scars of burnt areas using the Landsat/ETM sensor
}

\author{
Felix Carriello ${ }^{1}$ \\ ${ }^{1}$ Instituto Nacional de Pesquisas Espaciais - INPE \\ Caixa Postal 515 - 12227-010 \\ São José dos Campos - SP, Brazil \\ felix@dpi.inpe.br
}

\begin{abstract}
This study reports the investigation of spectral response changes in burnt events in a multitemporal data series. We have used 8 Landsat/ETM+ scenes for the year 2002. Based on pre-processing techniques of image geographic and radiometric normalization, classification methodology was carried out to detect burn scar areas. Samples of polygons were used to calculate mean and standard deviation values for the assessment of changes in the spectral domain of bands 1 to 5 and 7 to investigating how bands behavior in time. Then we applied an index to the images, utilizing bands 3 and 4 to detect burn scars. This index was tested and showed a consistent performance, enhancing the burned areas. Statistical test were carried out to evaluate differences among the values in each date. Results showed that there are statistical differences among dates, indicating that a burn took place in that date .
\end{abstract}

Key-words: burnt events, Burned Area Index, burned areas.

\section{Introduction}

Burnt events occur in all ecosystems and anthropogenic areas promoting local to regional impacts on land use, productivity and biodiversity; and also regional to global impacts through the modification of the hydrological cycle, biochemistry and geochemistry cycles and in the atmospheric processes [1]. The burning of forests produces carbonic gas mainly, contributing with about $90 \%$ of the emissions, being this, the main gas of the greenhouse effect [2].

The efficiency of the burnt event is an important aspect to estimate gas emissions of greenhouse effect in tropical forests [3]. According to these authors, the burning of forests varies in time and space. In their field work, they found that in 10 small plots of study in the Amazônia, the average of burnt efficiency is approximately $40 \%$. The persistence of ashes and coal signals varies in function of the climate, regimes of fire and the wooden amount, while the signal of the duration of the

\author{
Liana O. Anderson² \\ ${ }^{2}$ Oxford University Centre for the Environment - OUCE \\ South Parks Road, Oxford OX1 3QY - UK \\ lander@ouce.ox.ac.uk \\ Marcos Adami ${ }^{1}$ \\ adami@ltid.inpe.br
}

scars of forest fires depends on the productivity and vegetal covering [4].

There are two research lines related to detection and monitoring of burnt events: first line refers to the detention of hot spots, generally associate to active fires, that use the spectral bands of the region of the thermal infra-red [5], [6], [7] e [8]. The second line is related to the spatialization of forest fires. This is concentrated in the quantification of the extension of affected areas for this event, generally using spectral bands of the visible region and / or associates to spectral bands of thermal infra-red region, [9], [10], [1], [11], [12] and [13]. In this Context, this work investigates the forest fires, in the attempt to establish more precisely dates of burnt using the BAI (Burnt Area Index) proposed by Chuvieco, [14] to tests its accuracy in detecting scars of fire events.

\section{Study Area}

The study area is placed in the north of Estado de Mato Grosso, Brazilian Amazon, defined for the path/row 227/68, and its involving rectangle whose coordinates are W $57^{\circ} 41^{\prime}$ to $55^{\circ} 29^{\prime}$ and $\mathrm{S} 10^{\circ} 37^{\prime}$ to $12^{\circ} 30^{\prime}$. This area was selected according to crossing of three factors: higher index of deforestation, according to data of the PRODES Project Monitoramento da Floresta Amazônica por Satélite [15], higher index of forest fires, according to data of heat points supplied by the CPTEC, 2006 [16] and the availability of a temporal series of free cloud images. The characteristics of the study area are defined, according to Nimer [17] with an annual rainfall that reaches high values up to $2,700 \mathrm{~mm}$, however the annual regime of rainfall is different, with rainy summer (70 $\%$ of the annual precipitation occur among November to March) and dry winter. The region has average annual temperatures around $26^{\circ} \mathrm{C}$. 

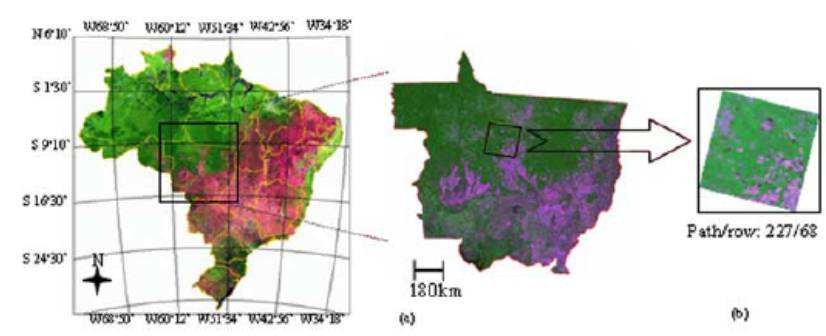

Fig. 1. Location of the study area. (a) Mato Grosso State located on the central west of Brazil [MODIS image mosaic (R-MIR (2105-2155 nm) G-NIR (841876nm) B-RED (620-670 nm))]. (b) The ETM+ 227/68 patch - row.

\section{Methodology}

8 ETM+ images were acquired initiating in the166 Julian day and all the following ones until 278 Julian day totalizing 8 dates of path/row 227/68 from 2002. Two bands (3 - red - and 4 - Near infrared) of each one of the dates had been used.

The images had been imported for a dataset and georeferenced on the basis of the same scene available at PRODES Project, with 0, 5 maximum pixel error.

First, radiometric and geographic normalization of the data were carried out, as a standard procedure in Land Cover Change (LCC) studies using remote sensing data. These preprocessing techniques were done to correct the radiometry among the images for data normalization and withdrawal the effects that can influence the spectral response, like changes in the solar angle elevation, phenology and also the modification of the satellite oscillations, like pitch, row and yaw. Then, the detection of burnt areas was carried out using Isoseg, a nonsupervised classification algorithm [18]. 47 polygons of burned areas had been acquired using the classifier with a $90 \%$ threshold. Then, we calculated mean and standard deviation for each band at each date.

BAI described by Chuvieco[14], was used to test its accuracy in detecting scars along the period. For this, we chose polygons that were burnt at Julian day 278, and after that, they were used to calculate mean for all scenes. The polygons had been numbered and used for the calculation of BAI in eight images. Mean of bands 3 and 4 (used to calculate BAI) to each Julian day had been calculated for each one of the samples.

After this, BAI was applied to bands 3 and 4 using the same parameters used in Spain by [14] and statistical tests were applied to verify if the results were different in these bands and dates.

\section{Results}

Mean and Standard deviation were calculated to the bands and 8 dates and figure 2 presents the results. Statistical tests $(p<0.05)$ showed that there are differences between bands between these date: between Julian Day 166 - Julian Day 182 among bands 3, 4 , 5 e 7. Between Julian Day 214-Julian Day 230 differences between bands 2 and 4. Between Julian Day 230-Julian Day 246 differences between bands 1 and 2 and Between Julian Day 262-Julian Day 278 differences between bands 2 and 7. This point out to a burn event occurring in these date.
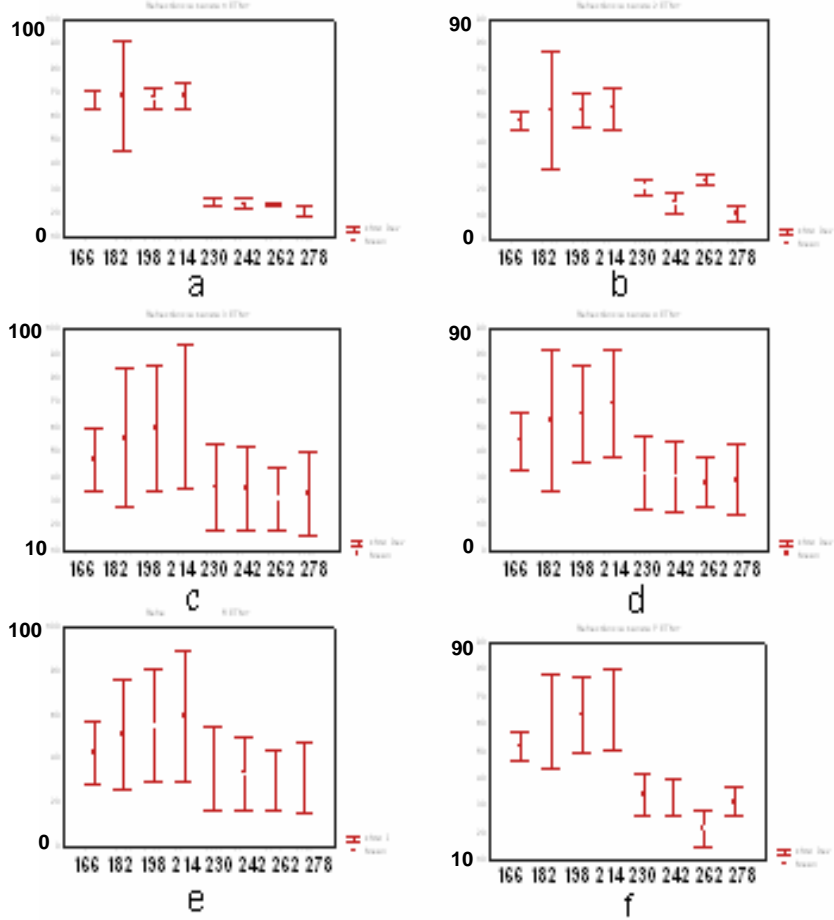

Figure 2-Spectral bands (digital numbers)-mean and standard deviation: a) Band 1, b) band 2, c) band 3, d) band 4, e) band 5 and $\mathrm{f}$ ) band 7 (dates in $\mathrm{x}$ axis, digital numbers in $\mathrm{y}$ axis).

The averages value of BAI for all dates is presented in figure 3. The first date (Julian day 166) has a higher average value that gradually decreases until the fourth date (Julian day 214). In addition, we observed that burnt events were easily detectable in the first date (higher average) indicating a recent burnt event, according to the statistical differences seen in bands 3, 4, 5 e 7 (between dates 166 and 182). At Julian day 230 , one can observes lower average values and the burnt events are not so clearly like the others scenes and targets (figure 3).

In dates 214-230, the BAI average value decreases, lesser than the initial date (Julian day 166). Statistical differences in 
bands 2 e 4 shows a burnt event must occurred in Julian Day 214. At Julian Day 246 a burnt event occurred because BAI has higher values and statistical differences between bands appear in bands 1 and 2. Between dates 246-262 BAI decreases and there are no statistical differences among bands. In dates 262-278 there is an increase in BAI, and statistical differences is found in bands 2 and 7 and another burn occurred.

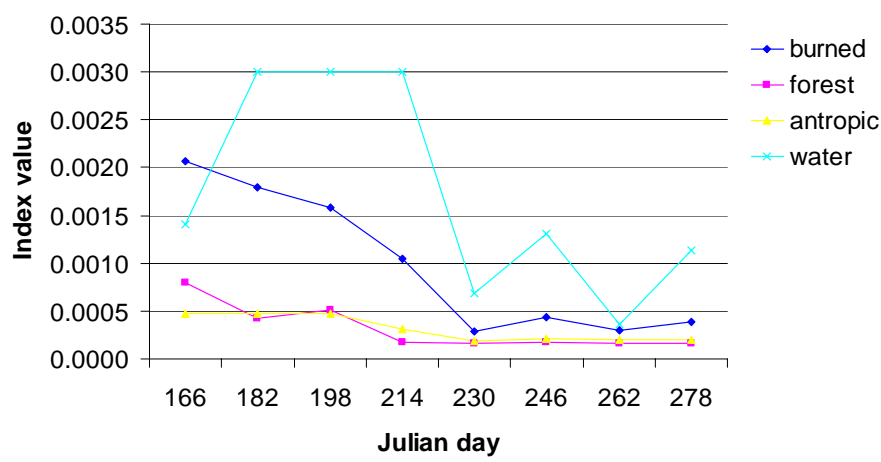

Figure 3 - Average values of BAI - different classes : burned area, forest, antropic area and water.

Statistical tests were applied between bands 3 and 4 showing significant differences (mean pixel value) between dates 166-182; 214-230 and 246-262. These could be an indicative of burn events occurred among these date. These differences are in accordance with variations of the reflectance of the BAI Index between dates 166-182; 214-230; 246-262.

\section{Conclusions}

In this study, we observed that BAI improves detection of recent scars when compared to single spectral bands signal. In addition, it enhanced the visualization of rivers due to the spectral similarity between these targets. Statistical tests showed that there was accordance with BAI and bands analyzed separately. This is useful information for investigations in the Amazon region, where burnt scars can disappear in the imagery rapidly due to climatic and soil conditions.

\section{ACKNOWLEDGMENT}

F. Carriello would like to thanks Geoma Project / MCT (Ministério da Ciência e Tecnologia) for the financial support. L.O. Anderson thanks the Brazilian government for the CAPES PhD scholarship, IEB/BECA for the financial support.

\section{References}

[1] Roy, D.P.; Lewis, P.E. e Justice, C.O. Burned area mapping using temporal moderate spatial resolution data - a bidirectional reflectance model-based expectation approach. Remote Sensing of Environment. V. 83 p.263-286. 2002
[2] Lashof, D.A. The contribution of biomass burning to global warming: an integrated assessment. In: Levine, J.S. (Ed.) Global biomass burning. Cambridge: MIT Press, p. 441-444, 1996.

[3] Fearnside, P.M.; Graça, P.M.L.A.; Leal, N.F.; Rodrigues, F.J.A., Robinson, J.M. Troppical forest burning in Brazilian Amazonia: measurement of biomass loading, burning efficiency and charcoal formation at Altamira, Pará. Forest Ecology and Management. V. 123 p.65-79, 1999

[4] Pereira, J.M.C.; Chuvieco, E.; Beaudoin, A.; Desbois N. Remote sensing of burned areas: a review. In: Chuvieco, E. (ed). A review of remote sensing methods for the study of large wildland fires. Alcalá de Henares: Universidad de Alcalá, 1997. p. 127-183.

[5] Justice, C.O.; Giglio, B.; Korontzi, S.; Owens, J.; Morisette, J.T.; Roy, D.P.; Descloitres, J.; Alleaume, S.; Petitcolin, F.; Kaufman, Y. 2002. The MODIS fire products. Remote Sensing of Environment, 83: 244-262.

[6] Giglio, L.; Descloitres, J.; Justice, C.O.; Kaufman, Y.J. 2003. An enhanced contextual fire detection algorithm for MODIS. Remote Sensing of Environment, 87 (2-3):273-282.

[7] Pergola, N.; Marchese, F.; Tramutoli, V. 2004. Automated detection of thermal features of active volcanoes by means of infrared AVHRR records. Remote Sensing of Environment, 43 (9): 2115-2126.

[8] Li, Y.; Vodacek, A.; Kremens, R.L.; Ononye, A.; Tang, C. 2005. A hybrid contextual approach to wildland fire detection using multispectral imagery. IEEE Transactions on Geoscience and Remote Sensing, 43 (9)2115-2126.

[9] Pereira, A.C.; Setzer, A.W. 1996. Comparison of fire in savannas using AVHRR's Channel 3 and TM images. International Journal of Remote Sensing, 17 (10): 1925-1937.

[10] Domenikiotis, C.; Dalezios, N.R.; Loukas, A.; Karteris, M. 2002. Agreement assessment of NOAA/AVHRR NDVI with Landsat TM NDVI for mapping burned forested areas. International Journal of Remote Sensing, 23 (20): 4235-4246.

[11] Stropiana, D.; Tansey, K.; Gregoire, J.M.; Pereira, J.M.C. 2003. An algorithm for mapping burnt areas in Australia using SPOTVEGETATION data. IEEE Transactions on Geoscience and Remote Sensing, 41 (4): 907 - 909.

[12] Gitas, I.Z.; Mitri, G.H.; Ventura, G. 2004. Object-based image classification for burned area mapping of Creus Cape, Spain, using NOAA-AVHRR imagery. Remote Sensing of Environment, 92 (3): 409-413.

[13] Silva, J.M.N.; Sá, A.C.L.; Pereira, J.M.C. 2005. Comparison of burned area estimates derived from SPOT-VEGETATION and Landsat ETM+ data in Africa: Influence of spatial pattern and vegetation type. Remote Sensing of Environment, 96 (2): 188-201.

[14] Chuvieco, E. Martín, M.P. e Palacios, A. Assessment of different spectral indices in the red-near infrared spectral domain of burned land discrimination. International Journal of Remote Sensing. v. 23. n. 23. p. 5103-5110. 2002

[15] INPE, Instituto Nacional de Pesquisas Espaciais, 2006. disponível em:< http:// http://www.obt.inpe.br/prodes/> Access em september, 13t, 2006

[16] CPTEC, Centro de Previsão e Estudos Climáticos, 2006 disponível em:<http://www.cptec.inpe.br/queimadas/> Access em september, 13t, 2006

[17] Nimer, E. Clima. Geografia do Brasil. Região Centro-Oeste. Rio de Janeiro: IBGE, 1977. 364 p.

[18] Bins, L.S.; Erthal, G.J.; Fonseca,L.M.G. Um método de classificação não supervisionada por regiões. In: Simpósio Brasileiro de Computação Gráfica e Processamento de Imagens, 7., 1993, Recife. Anais. São José dos Campos: INPE, v. 4, p. 65-68, 2001. Seção Comunicações. 